\title{
Relationship between Depressive Symptoms and Stigma with the Need and Willingness to Receive Counseling Services among Public University Students in Sarawak
}

Muhammad Abdul Rahim bin Habib, Noor Syamilah Zakaria, Amirul Azuan Md Joni, Wan Norhayati Wan Othman, Faizul Adenan

To Link this Article: http://dx.doi.org/10.6007/IJARBSS/v12-i1/10920

DOI:10.6007/IJARBSS/v12-i1/10920

Received: 18 November 2021, Revised: 20 December 2021, Accepted: 30 December 2021

Published Online: 16 January 2022

In-Text Citation: (Habib et al., 2022)

To Cite this Article: Habib, M. A. R. bin, Zakaria, N. S., Joni, A. A. M., Othman, W. N. W., \& Adenan, F. (2022). Relationship between Depressive Symptoms and Stigma with the Need and Willingness to Receive Counseling Services among Public University Students in Sarawak. International Journal of Academic Research in Business and Social Sciences, 12(1), 1084-1097.

Copyright: @ 2022 The Author(s)

Published by Human Resource Management Academic Research Society (www.hrmars.com) This article is published under the Creative Commons Attribution (CC BY 4.0) license. Anyone may reproduce, distribute, translate and create derivative works of this article (for both commercial and non0-commercial purposes), subject to full attribution to the original publication and authors. The full terms of this license may be seen at: http://creativecommons.org/licences/by/4.0/legalcode

Vol. 12, No. 1, 2022, Pg. $1084-1097$

Full Terms \& Conditions of access and use can be found at http://hrmars.com/index.php/pages/detail/publication-ethics 


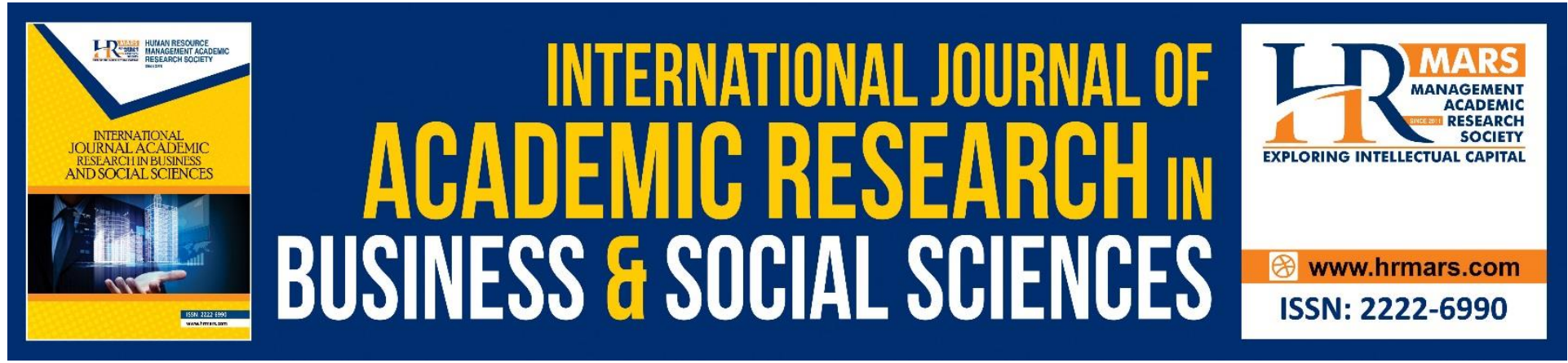

\title{
Relationship between Depressive Symptoms and Stigma with the Need and Willingness to Receive Counseling Services among Public University Students in Sarawak
}

Muhammad Abdul Rahim bin Habib, Noor Syamilah Zakaria Department of Caunselor Education and Caunseling Psychology, Faculty of Educational

Studies, Universiti Putra Malaysia 43400 UPM Serdang, Selangor, Malaysia

\author{
Amirul Azuan Md Joni
}

Department of Environmental Sciences, Faculty of Forestry and Environment, Universiti Putra Malaysia, 43400 UPM Serdang, Selangor, Malaysia

\section{Wan Norhayati Wan Othman}

Department of Caunselor Education and Caunseling Psychology, Faculty of Educational Studies, Universiti Putra Malaysia 43400 UPM Serdang, Selangor, Malaysia

\section{Faizul Adenan}

Faculty of Medicine and Health Sciences, Universiti Malaysia Sarawak

\begin{abstract}
This study aimed to identify the relationship between depressive symptoms and stigma with the need and willingness to seek counselling services. Pearson's correlation, t-test and ANOVA was applied in this study to obtain the direction and strength of the relationship that exists between the variables. A total of 348 university students aged 18 to 26 years and above were involved in this study which was conducted at a public university in Sarawak. The findings of the study indicate that there is a positive correlation between the variables of depressive symptoms and stigma with readiness and the need to seek counselling. While there is a difference in depressive symptoms reported higher among the group who had sought counselling compared to the group who had never sought counselling. Even so, the group that never sought counselling was reported to have higher differences from stigma and the need and willingness to seek counselling. ANOVA analysis showed that there was no significant difference between the Cumulative Grade Point Average (CGPA) among students in public universities on depressive symptoms. The main implications of this study lead to the improvement of counselling services in universities to improve the existing counselling system and management.
\end{abstract}




\section{Introduction}

The past decade has shown the mental health crisis to be the biggest challenge in most universities in the world (Auerbach et al., 2018). Studies show the level of mental health of poor students in colleges and universities has increased as much as to $51 \%$ in some countries (Auerbach et al., 2018). More than 90\% of counselling centre directors expressed concern about the rise of mental health problems among college and university students such as anxiety disorders, crises requiring an emergency response, psychiatric medication issues, clinical depression, learning difficulties, sexual harassment on campus, self -harm and related cases of abuse sexual in the past (Gallaher, 2015). Current mental health problems at university are also associated with an increased risk of substance abuse, a significant decline in quality of life and suicidal thoughts and behaviours (Mortier et al., 2018; Pedrelli et al., 2016).

Most of the studies reported that the problem of mental health issues among universities is increasingly at an alarming level (Blanco et al., 2008; Karam, Kypri \& Salamon, 2007; Stallman, 2008). A study of 617 students at a private university in Selangor showed that 65 percent of respondents experienced depressive symptoms as a result of online learning during movement control commands (Ads et al., 2020). In addition, the results of the study showed that low internet coverage has resulted in 65 percent of study respondents experiencing depressive symptoms (Ads et al., 2020). According to Bukhari \& Saba (2017), university students are a group of individuals who are going through the age of transition between adolescence and adulthood. They have to face challenges in life such as living away from family, adjusting to strangers and more. At the same time, they can be exposed to various sources of stress. These causes of stress if not handled properly can lead to depression in turn affecting life satisfaction (Bukhari \& Saba, 2017).

Depression is a frequent mental disorder and can have a negative impact on an individual's life (APA, 2013), including among university students (Gallagher, 2009). Depression can have a major impact on students' lives and can affect academic performance (Hysenbegasi et al. (2005), physical health as well as despair (Taliaferro et al., 2009), motivation, self-injury (Bonne \& Brausch, 2016), ultimately behaviour and suicide attempts (Vázquez \& Blanco, 2006).

There are several factors that influence the behaviour of seeking psychological help especially among college students who experience depression while in a critical phase in early adulthood (Wang et. al. 2015). Wang et al. (2015) have suggested that the behaviour of seeking psychological help can be improved by understanding stigma. This will help university or college students to seek help earlier and subsequently, seek immediate treatment in anticipation of more positive treatment outcomes. Stigma in seeking psychological help is often associated with stereotypes such as pernicious mental illness (Tucker et al., 2013).

Several studies have documented the trend of mental health problems among university students that are poorly explained and there are still knowledge gaps about the determinants that cause rising rates of mental health problems (Bruffaerts et al., 2018; Ngin et al., 2018). In Malaysia, several studies have been conducted to identify the level of depression among university students. Islam et al. (2019) explained in a study, 29.4 percent of public university students in Kuala Lumpur experienced depressive symptoms. Minhat and Alawad (2019) 
found that 31.1 percent of medical students had symptoms of depression at one of the public universities in Selangor.

Self-stigma also hinders early decisions to seek mental health information and counselling (Lannin et al., 2016). According to Nokman (2018), stigma and discrimination related to mental illness have been a major barrier for those living with mental health problems to seek psychological treatment. The Ministry of Health Malaysia $(\mathrm{MOH})$ face the same difficulties to approach this group due to this negative stigma (Nokman, 2018). The study conducted by Eisenberg et al (2011) found that university students have a sceptical view of counselling because they prefer to deal with problems alone, question the effectiveness of counselling in problem-solving, believe stress as normal, consider counselling less helpful and worry about the views of others when seeking counselling. About 12 percent of university students admit that they have stigma and feel uncomfortable when discussing personal problems with a counsellor (Czyz, 2013).

Reports from the World Health Organization (WHO) indicate that many people with mental health problems are most likely not to engage in or seek help from any mental assistance services because of stigma and discrimination (WHO, 2013). However, based on past studies, there is a link between individuals' perceptions of needing help and use of mental health services, showing that 50 percent of students with mental health problems who feel they need help receive treatment compared to only $11 \%$ who don't feel they have a problem in need help (Eisenberg et al., 2011).

Therefore, this study will look at the relationship whether there is relationship between depressive symptoms and stigma with the need and willingness to seek counselling services among university students in Sarawak. In addition, related studies on this topic by taking into account the population of university students in Sarawak allows a comparison of the results of previous studies that mostly take into account the student population in Peninsular Malaysia. In addition, this study will look at the pandemic impact of COVID-19 and movement control orders on students during the course of the study.

\section{Research Methodology}

Pearson's correlation was applied in this study in order to identify the relationships between the variables. A public university in Sarawak was selected for the COVID-19 pandemic during the Movement Control Order in Malaysia. Non -random sampling is a technique was chosen in this study. It can be achieved through selecting a sample from a population in which each individual in the population does not have the same opportunity or probability in the selection process as the sample. The selected individual may be coincidental or even selected because the individual is believed to be able to provide the required information. As such, not all individuals have the same opportunity to be selected as a sample (Othman, 2013).

Researchers have used two methods to determine the sample size by using the formula of Krejcie and Morgan (1970) and power analysis by Cohen (1988) to ensure that two sampling criteria are met namely representation and adequacy (Ary et al., 2006). Through these two methods, the optimal sample required is 348 people where a decision related to the null hypothesis can be made by reducing the risk of committing Type I error and Type II error. 
This study uses a set of questionnaires for data collection this questionnaire consists of three parts. Part A consists of personal information, Part B is part of a questionnaire to determine the depressive symptoms using the Center For Epidemiology Study Depression Scale (CESD) which was developed by (Laurie Radloff in 1977). Part C is the Self-stigma of Seeking Help Scale (SSOSHS) ) developed by Vogel et al (2006) while Part D is a questionnaire that measures attitudes toward seeking counselling help, using the Attitudes Towards Seeking Professional Psychological Help- Short Form (ATSPPH-SF) questionnaire produced by (Fischer \& Turner, 1995).

\section{Findings}

\section{Respondent Demographic Background}

Based on Table 10, the respondents involved in the analysis of this study were a total of 348 people, consisting of 114 (32.8\%) male respondents and 234 (67.2\%) female respondents. The majority of respondents were Malay with a total of 180 (51.7\%), followed by 87 (25\%) respondents Sarawak Bumiputera ethnic groups, 43 (12.4\%) respondents from Bumiputera Sabah. 26 (7.2\%) respondents were Chinese and the remaining 13 (3.7\%) people were Indians. In addition, a total of $228(65.5 \% \%)$ of the respondents involved are Muslims, 97 (27.9\%) people are Christians, 13 (3.7\%) people are Buddhists and 9 (2.6\%) people are Hindus.

Based on age status, the majority of $132(46.12 \%)$ respondents aged between 18 to 19 years followed by 103 (36.6\%) respondents aged between 20 to 21 people, $60(17.3 \%)$ respondents aged between 22 to 23 years, 21 (6\%) respondents aged between 24 to 25 years and the remaining $7(2 \%)$ respondents aged 26 and above. While the field of study is taken by the majority of respondents from the diploma program which is 251 (72.1\%) people followed by bachelor students which are $94(27 \%)$ people and $3(0.9 \%)$ respondents are students preparing for a science diploma.

Next, for the Cumulative Grade Point Average (CGPA) status, 236 (67.8\%) respondents got CGPA from 3.00 to $3.749,61$ (17.5\%) respondents got CGPA from 3.750 to $4.000,42$ (12.1\%) respondents got CGPA from 2,250 to 2,999, 5 (1.4 \%) respondents got a CGPA from 2,000 to 2,249 and $4(1.1 \%)$ respondents got a CGPA from 1,999 to 1,000. Finally, in terms of family income, the majority of respondents have income below RM4,850 (B40) which is 224 (64.4\%) people and followed by family income from RM4,850 to RM10,959 (M40) which is 101 (29\%) people and finally the family income exceeds RM10,960 (T20) which is 23 (6.6\%) respondents. 
Table 1. Frequency distribution of demographic aspects of respondents

\begin{tabular}{|c|c|c|}
\hline Aspek demografi & Frekuensi & Peratus \\
\hline \multicolumn{3}{|l|}{ Gender } \\
\hline Male & 114 & $32.8 \%$ \\
\hline Female & 234 & $67.2 \%$ \\
\hline \multicolumn{3}{|l|}{ Ethnic } \\
\hline Malay & 180 & $51.7 \%$ \\
\hline Chinese & 25 & $7.2 \%$ \\
\hline Indian & 13 & $3.7 \%$ \\
\hline Local Sarawak & 87 & $25 \%$ \\
\hline Local Sabah & 43 & $12.4 \%$ \\
\hline \multicolumn{3}{|l|}{ Religion } \\
\hline Muslim & 228 & $65.5 \%$ \\
\hline Christian & 97 & $27.9 \%$ \\
\hline Buddha & 13 & $3.7 \%$ \\
\hline Hindu & 9 & $2.6 \%$ \\
\hline \multicolumn{3}{|l|}{ Age } \\
\hline 18-19 & 132 & $46.12 \%$ \\
\hline $20-21$ & 103 & $36.8 \%$ \\
\hline $22-23$ & 60 & $17.3 \%$ \\
\hline $24-25$ & 21 & $6 \%$ \\
\hline 26 and above & 7 & $2 \%$ \\
\hline \multicolumn{3}{|l|}{ Field of Study } \\
\hline Bachelor & 94 & $27 \%$ \\
\hline Diploma & 251 & $72.1 \%$ \\
\hline Diploma of Science Preparation (ASASI) & 3 & $0.9 \%$ \\
\hline \multicolumn{3}{|l|}{ Cumulative Grade Point Average (CGPA) } \\
\hline $3.750-4.000$ & 61 & $17.5 \%$ \\
\hline $3.000-3.749$ & 236 & $67.8 \%$ \\
\hline $2.250-2.999$ & 42 & $12.1 \%$ \\
\hline $2.000-2.249$ & 5 & $1.4 \%$ \\
\hline 1.999- 1.000 & 4 & $1.1 \%$ \\
\hline \multicolumn{3}{|l|}{ Family Income } \\
\hline Below RM4,850 (B40) & 224 & $64.4 \%$ \\
\hline RM4,850 - RM10,959 (M40) & 101 & $29 \%$ \\
\hline Above RM10,960 (T20) & 23 & $6.6 \%$ \\
\hline
\end{tabular}

Experience using Counselling Services

Table 2 shows that a total of 122 (35.1\%) people out of 348 respondents reported to used counselling services and 226 (64.9\%) people had never obtained such services. 
Table 2. Frequency distribution of experience using counseling services

\begin{tabular}{|c|c|c|c|c|c|}
\hline $\begin{array}{l}\text { Symptoms of } \\
\text { Depression }\end{array}$ & $\begin{array}{c}\text { Number } \\
\text { of } \\
\text { Students }\end{array}$ & Mean & $\begin{array}{l}\text { Standard } \\
\text { Deviation }\end{array}$ & t-value & $\begin{array}{l}\text { Significant } \\
\text { (p) }\end{array}$ \\
\hline Group of Students & & & & 2.26 & .024 \\
\hline $\begin{array}{l}\text { Received } \\
\text { Counselling Services }\end{array}$ & 122 & 2.51 & 0.76 & & \\
\hline $\begin{array}{l}\text { Never Received } \\
\text { Counselling Services }\end{array}$ & 226 & 2.31 & 0.81 & & \\
\hline \multicolumn{3}{|c|}{ Experience using counseling services } & \multicolumn{2}{|c|}{ Frequency } & Percentage \\
\hline \multicolumn{6}{|c|}{ Experience using counselling services } \\
\hline \multicolumn{3}{|c|}{ Yes } & \multicolumn{2}{|c|}{122} & $35.1 \%$ \\
\hline \multicolumn{3}{|c|}{ No } & \multicolumn{2}{|c|}{226} & $64.9 \%$ \\
\hline
\end{tabular}

\section{Levels of Depressive Symptoms}

According to Table 3, the analysis shows that 202 (58.05\%) respondents have symptoms of depression with severe level, followed by a moderate to low level of 75 (21.55\%) people and a mild level and none of the 71 (20.40\%) people. Researchers have conducted this research during the COVID19 Pandemic and the Movement Control Order were implemented during this period, which can affect depressive symptoms. Based on the study that had been done by Shah et al(2021), which involving 678 respondents from various countries within almost the same circumstances, there were $58.6 \%$ of respondents experienced depressive symptoms had been reported.

Table 3. Frequency distribution of depressive symptoms

\begin{tabular}{lcccc}
\hline \multicolumn{1}{c}{ Variables } & Frequency & Percentage & Mean & SD \\
\hline $\begin{array}{l}\text { Symptoms of } \\
\text { Depression }\end{array}$ & & & 27.91 & 12.62 \\
\hline Severe & 202 & 58.05 & & \\
Moderate & 75 & 21.55 & & \\
Low to none & 71 & 20.40 & & \\
\hline
\end{tabular}

\section{Level of Stigma}

Based on Table 4, the analysis shows that 240 (68.97\%) respondents have a moderate level of stigma followed by a low level of stigma of 94 (27.1\%) people and a high level of stigma of 14 (4.02\%) people. Study by Rohaizad et al. (2019) has displayed similarities when the majority of respondents who are at moderate stigma levels get the highest percentage compared to other levels. 
Table 4. Stigma's frequency distribution

\begin{tabular}{lccccc}
\hline \multicolumn{1}{c}{$\begin{array}{c}\text { Symptoms of } \\
\text { Depression }\end{array}$} & $\begin{array}{c}\text { Number } \\
\text { of } \\
\text { Students }\end{array}$ & Mean & $\begin{array}{c}\text { Standard } \\
\text { Deviation }\end{array}$ & t-value & $\begin{array}{c}\text { Significant } \\
(\mathbf{p})\end{array}$ \\
\hline $\begin{array}{l}\text { Group of Students } \\
\text { Received }\end{array}$ & 122 & 2.51 & 0.76 & 2.26 & .024 \\
$\begin{array}{l}\text { Counselling Services } \\
\text { Never Received } \\
\text { Counselling Services }\end{array}$ & 226 & 2.31 & 0.81 & & \\
\hline
\end{tabular}

The Level of need and Readiness of Students in Obtaining Counselling Services

The researcher found that the majority of the respondents have a moderate level of need and willingness to seek counselling services based on the feedback received from $212(60.92 \%)$ respondents. Next 126 (36.21\%) people expressed high attitudes and only 11 (3.16\%) people were observed to have low attitudes towards counselling services. Table 5 summarizes the findings obtained.

Table 5. Frequency distribution of students' needs and readiness in obtaining counseling services

\begin{tabular}{lcccc}
\hline \multicolumn{1}{c}{ Variables } & Frequency & Percentage & Mean & SD \\
\hline Stigma & & & 26.74 & 5.70 \\
Low & 94 & 27.01 & & \\
Moderate & 240 & 68.97 & & \\
High & 14 & 4.02 & & \\
\hline
\end{tabular}

Differences in Depressive Symptoms based on Groups of Students who had and Never Sought Counselling

The mean values in Table 6 show that the group of students who had received counselling ( $M$ $=2.51, \mathrm{SP}=0.76)$ had higher depressive symptoms than the group of students who had never received counselling $(M=2.31, S P=0.81)$. $t$-test analysis reveals that there are significant different between this two group with $p<.05$. Thus, the conclusion made was that there was a significant difference in depressive symptoms between the group of students who had sought for counselling and had never sought counselling, $t(348)=2.26, p=.02$.

Table 6. Differences in depressive symptoms based on groups of students who had received and never reveived counseling services

\begin{tabular}{lcccc}
\hline \multicolumn{1}{c}{ Variables } & Frequency & Percentage & Mean & SD \\
\hline Counseling Needs & & & 18.88 & 5.03 \\
and Readiness & & & & \\
Low & 11 & 3.16 & & \\
Moderate & 212 & 60.92 & & \\
High & 126 & 36.21 & & \\
\hline
\end{tabular}




\section{Stigma Differences are based on Groups of Students who had Received and Never Reveived Counseling Services}

The mean values in Table 7 show that the group of students who had never received counselling $(\mathrm{M}=1.80, \mathrm{SP}=0.48)$ had a higher stigma than the group of students who had received counselling $(M=1.72, S P=0.55)$. Based on the findings obtained from the t-test analysis, the significant value of $p<.05$. Thus, there was a significant stigma difference between the group of students who had ever sought counselling and had never sought counselling, $t(348)=1.32, p=.019$. Based on the findings of this study, the group of students who have never received counselling has a higher stigma than the group who have received counselling. This situation is illustrated by Modified Labeling Theory (Link et al., 1989) which asserts that stigma against individuals seeking psychological services can cause individuals to shy away from such services and ultimately be exposed to risks that could harm themselves.

Table 7. Stigma differences based on groups of students who had received and never reveived counseling services

\begin{tabular}{llllll}
\hline Stigma & $\begin{array}{l}\text { Number } \\
\text { of } \\
\text { Students }\end{array}$ & Mean & $\begin{array}{l}\text { Standard } \\
\text { Deviation }\end{array}$ & t-value & $\begin{array}{l}\text { Significant } \\
\text { (p) }\end{array}$ \\
\hline $\begin{array}{l}\text { Group of Students } \\
\text { Received }\end{array}$ & 122 & 1.72 & 0.55 & -1.32 & 0.19 \\
$\begin{array}{l}\text { Counselling } \\
\begin{array}{l}\text { Services } \\
\text { Never Received }\end{array}\end{array}$ & 226 & 1.80 & 0.48 & & \\
$\begin{array}{l}\text { Counselling } \\
\text { Services }\end{array}$ & & & & & \\
\hline
\end{tabular}

Differences in Need and Willingness in Seeking Counselling Services based on Groups of Students who had Received and Never Reveived Counseling Services

The mean value in Table 8 shows that the group of students who have never received counselling $(\mathrm{M}=2.25, \mathrm{SP}=0.55)$ have a higher need and willingness to seek counselling services than the group of students who have received counselling $(M=1.72, S P=0.49)$. $t$ test analysis reveals that there are significant different between this two group with $p<.05$. Therefore, the conclusion made is that there is a significant difference in need and willingness in obtaining counselling services between the group of students who have received counselling and have never received counselling, $t(348)=-1.97, p=.05$.

Table 8. Differences in needs and willingness to obtain counseling services based on groups of students who had received and never reveived counseling services

\begin{tabular}{lccccc}
\hline $\begin{array}{l}\text { Needs and } \\
\text { willingness to seek } \\
\text { counseling services }\end{array}$ & $\begin{array}{c}\text { Number of } \\
\text { Students }\end{array}$ & Man & $\begin{array}{l}\text { Standard } \\
\text { Deviation }\end{array}$ & t-value & Significant \\
\hline $\begin{array}{l}\text { Group of Students } \\
\text { Received } \\
\text { Counselling }\end{array}$ & 122 & 2.25 & 0.49 & -1.97 & 0.05 \\
$\begin{array}{l}\text { Services } \\
\text { Never Received }\end{array}$ & 226 & 2.37 & 0.55 & & \\
$\begin{array}{l}\text { Counselling } \\
\text { Services }\end{array}$ & & & & & \\
\hline
\end{tabular}


The Relationship between Depressive Symptoms and the Need and Willingness to seek Counselling Services among Public University Students in Sarawak

Pearson correlation analysis showed a $p$-value $<0.01$ and this value was lower than the $\alpha$ value that had been set at 0.05 . Thus, Ho4 was rejected and this meant that there was a significant relationship between depressive symptoms and attitude to seek counselling services among adults, $r=0.287, p<0.01$. The value of correlation coefficient $r=0.29$, signify that the relationship that exists between depressive symptoms and the need and willingness to seek counselling services has a significant positive relationship. Table 9 shows the data obtained through Pearson correlation analysis. Thus, it can be concluded that higher symptoms of depression will cause higher propensity of the respondents to seek counselling services. This is in line as explained by Cramer's (1999) Model which describes the higher the stress faced by an individual, the more motivated a person's desire to seek counselling services.

Table 9. The relationship between depressive symptoms and the need and willingness of people to seek counseling services

\begin{tabular}{lccc}
\hline & $\begin{array}{c}\text { Needs and willingness } \\
\text { to seek counseling } \\
\text { services } \\
\text { (Correlation coefficient, } \\
\mathbf{r} \text { ) }\end{array}$ & $\begin{array}{c}\text { Significant } \\
\text { value }\end{array}$ & Interpretation \\
\hline $\begin{array}{l}\text { Symptoms of } \\
\text { depression }\end{array}$ & $0.29^{* *}$ & $<0.01$ & $\begin{array}{c}\text { Positive } \\
\text { relationship }\end{array}$ \\
\hline
\end{tabular}

The Relationship between the Level of Stigma with the Need and Willingness to Seek Counselling Services among Public University Students in Sarawak

Pearson correlation analysis showed a significant value of $p<0.01$ and this value was lower than the $\alpha$ value that had been set at 0.05 . Thus, this means that there is a significant relationship between stigma and attitude to seek counselling services among adults, $r=0.376$, $p<0.01$. The value of the correlation coefficient of $r=0.38$ means that there is a relationship between stigma with the need and willingness among those in received counselling services has a positive relationship. Table 10 shows the data obtained through Pearson correlation analysis. Thus, it can be concluded that the higher the stigma, the higher the propensity of the respondents to seek counselling services. Modified Labeling Theory (Link, 1989) is a label given by the community to counselling services, which can have an impact on individuals to get counselling services. The findings of this study have been contradicted by Pheng \& Jaafar (2019) who found that there was a significant negative relationship between stigma and counseling-seeking attitudes among 1,715 undergraduate students in public universities.

Table 10. The relationship between the level of stigma with the need and willingness among those to seek counselling services

\begin{tabular}{llll}
\hline & $\begin{array}{l}\text { Needs and readiness among } \\
\text { those to seek counselling } \\
\text { services } \\
\text { (Correlation coefficient, } r \text { ) }\end{array}$ & $\begin{array}{l}\text { Significant } \\
\text { value }\end{array}$ & Interpretation \\
\hline Stigma & $0.376^{* *}$ & $<0.01$ & $\begin{array}{l}\text { Positive } \\
\text { correlation }\end{array}$ \\
\hline
\end{tabular}


Significant differences in depressive symptoms based on the category of Cumulative Grade Point Average (CGPA) among public university students in Sarawak

Table 11 shows that one-way ANOVA analysis test to determine the significant differences in depressive symptoms based on the category of Overall Grade Point Average (CGPA) among students that is between CGPA $3.750-4.000,3.000-3.749,2.250-2.999,2.000-2.249$ and 1.999 - 1.000. The results of one -way ANOVA test was obtained were significant where the value of $F(4,343)=0.832, p>0.05$. Thus the ANOVA test showed that there was no significant difference between the Cumulative Grade Point Average (CGPA) among students in public universities on depressive symptoms.

Table 11. Significant differences in depressive symptoms based on the Cumulative Grade Point Average (CGPA) category

\begin{tabular}{|c|c|c|c|c|c|c|}
\hline & & JKD & Dk & MKD & F. & Sig. \\
\hline \multirow{6}{*}{$\begin{array}{c}\text { Cumulative } \\
\text { Grade Point } \\
\text { Average } \\
\text { (CGPA }\end{array}$} & Between & 2.149 & 4 & .537 & .832 & .506 \\
\hline & Group & & & & & \\
\hline & & & & & & \\
\hline & Within & 221.538 & 343 & .646 & & \\
\hline & Group & & & & & \\
\hline & Total & 223.687 & 347 & & & \\
\hline
\end{tabular}

\section{Discussion}

This study was conducted to explore the role of depressive symptoms and stigma on public university students in Sarawak to seek counselling services. Background demographic study showed that the majority of respondents were diploma students, women, aged between 18 years to 26 years of age, ethnic Malay and within the B40 family group. The majority of students involved in this study obtained CGPA results between 3.00 to 3.749. Most of the respondents in this study had never used counselling services during their study period in the local university. Researchers found that family members and friends were the first sources to refer whenever they experiencing conflict. Counsellors, on the other hand, are placed as a second choice as individuals are referred to in the event of a conflict.

The findings of this study found that the level of severe depressive symptoms was the highest percentage obtained by the researchers. Researchers have conducted this research when the COVID-19 Pandemic and Movement Control Order are underway in Malaysia which can affect depressive symptoms. Shah et al. (2021) confirmed nearly 58.6 percent suffer from depression as a result of experiencing quarantine and curfews. In addition, the group of students who had undergone counselling had higher depressive symptoms than the group of students who had never received counselling. The association of the elements of the level of severe depressive symptoms with the needs of students who have attended counselling sessions is seen as a need for students to continue to undergo counselling sessions. Beck (2003) believes individuals with depression often focus on the negative aspects of the situation while ignoring the positive. They tend to twist and misinterpret information to the point of cognitive bias.

In terms of stigma, the findings also show that the majority of students surveyed have placed stigma at a moderate level. In addition, the group of students who had never received counselling had a higher stigma than the group of students who had received counselling. This 
statement is reinforced by the Modified Labelling Theory (Link et al., 1989) which states that stigma against individuals seeking psychological services can cause individuals to stay away from those services.

Meanwhile, the majority of respondents placed the level of readiness and need for counselling services at a moderate level followed by high and low levels. In addition, the results of this study also show that the group of students who have never received counselling have a higher need and willingness to seek counselling services than the group of students who have received counselling.

Based on this study, there is a significant positive relationship between depressive symptoms and the need and willingness to seek counselling services. Through this relationship, it can be concluded that the higher the symptoms of depression, the higher the propensity of the respondents to seek counselling services. This is supported by Cramer's (1999) Model which describes the higher the stress faced by an individual, the more motivated a person's desire to seek counselling services.

This study also found that there is a relationship that exists between stigma and the need and willingness to seek counseling services has a significant positive relationship. Thus, it can be concluded that the higher the stigma, the higher the propensity of the respondents to seek counseling services. The findings of this study have been contradicted by Pheng \& Jaafar (2019) who found that there was a significant negative relationship between stigma and counseling-seeking attitudes among 1,715 undergraduate students in public universities. While ANOVA analysis shows that there is no significant difference between the Overall Grade Point Average (CGPA) among students in public universities on depressive symptoms. Therefore, depressive symptoms were not affected by the Cumulative Grade Point Average (CGPA).

\section{Summary}

This study shows a positive relationship between depressive symptoms with stigma and the need and awareness to seek counseling services. It is also found that there are high levels of depressive symptoms among university students in Sarawak during the covid-19 pandemic period. A comparison between the group that had received counseling services and the group that had never received counseling serviced showed that the group that had never received counseling need to obtain counseling services. While Anova's analysis shows there was no significant difference between the CGPA of university students with depressive symptoms.

It can be said that the covid-19 pandemic period had an impact on student psychology in terms of depressive symptoms. Due to this circumstance, the university should have simple approaches to get psychological help such as tele-counseling. In addition, universities counselors should promote counseling services to reduce the stigma towards counseling. Peer-helpers based programs can also be a psychological support system to help students as can be seen from the results, students prefer to recount personal conflicts to their peers. An intervention module should be implemented in the future in order to help students to deal with stigma in seeking counseling to reduce students facing depressive symptoms. 


\section{References}

Ads, H. O., Ghazi, H. F., Faez, M., Hadi, J., Abdalqader, M., \& Assem, H. (2020). Impact of Lockdown Due to Covid-19 on Mental Health among Students in Private University at Selangor. European Journal of Molecular \& Clinical Medicine, 7(11), 508-517.

Auerbach, R. P., Mortier, P., Bruffaerts, R., Alonso, J., Benjet, C., Cuijpers, P., ... \& Kessler, R. C. (2018). WHO world mental health surveys international college student project: prevalence and distribution of mental disorders. Journal of abnormal psychology, 127(7), 623. doi: 10.1037/abn0000362

American Psyhiatric Association . (2013), Diagnostic and statistical manual of mental disorders $\left(5^{\text {th }}\right.$ ed). Arlington, VA.

Blanco, C., Okuda, M., Wright, C., Hasin, D. S., Grant, B. F., Liu, S. M., \& Olfson, M. (2008). Mental health of college students and their non-college-attending peers: results from the national epidemiologic study on alcohol and related conditions. Archives of general psychiatry, 65(12), 1429-1437.

Beck, A. T. (2003). Cognitive therapy of depression. Guilford Press.

Bukhari, S. R., \& Saba, F. (2017). Depression, anxiety and stress as negative predictors of life satisfaction in university students. Rawal Medical Journal, 42(2), 255-257.

Boone, S. D., \& Brausch, A. M. (2016). Physical activity, exercise motivations, depression, and nonsuicidal self-injury in youth. Suicide and Life-Threatening Behavior, 46(5), 625-633.

Eisenberg, D., Hunt, J., Speer, N., \& Zivin, K. (2011). Mental health service utilization among college students in the United States. The Journal of nervous and mental disease, 199(5), 301-308.

Faizura, R., Rusnani, A.K., Rahimah I. (2014). Hubungan antara stigma masyarakat dan stigma kendiri terhadap sikap untuk mendapatkan perkhidmatan kaunseling. Jurnal Pendidikan Bitara UPSI, Volume 7, 106-113.

Fischer, E. H., \& Farina, A. (1995). Attitudes Toward Seeking Professional Psychological Help Scale--Short Form [Database record]. APA PsycTests. https://doi.org/10.1037/t05375000

Gallagher, R. P. (2009). National survey of counseling center directors 2008.

Gallagher, R. P. (2015). National Survey of College Counseling Centers $2014 . \quad$ Retrieved from https://core.ac.uk/download/pdf/43007621.pdf.

Karam, E., Kypri, K., \& Salamoun, M. (2007). Alcohol use among college students: an international perspective. Current opinion in psychiatry, 20(3), 213-221.

Lannin, D. G., Vogel, D. L., Brenner, R. E., Abraham, W. T., \& Heath, P. J. (2016). Does selfstigma reduce the probability of seeking mental health information? Journal of Counseling Psychology, 63(3), 351 358. doi:10.1037/cou0000108

Link, B. G., \& Phelan, J. C. (2001). Conceptualizing stigma. Annual Review Sociology, 27, 363385.

Mortier, P., Auerbach, R. P., Alonso, J., Axinn, W. G., Cuijpers, P. \& Ebert, D. D. (2018). Suicidal thoughts and behaviors among college students and sameaged peers: Results from the World Health Organization World Mental Health Surveys. Soc. Psychiatry Psychiatr. Epidemiol. 53, 279-288. doi: 10.1007/s00127-018-481-6

Othman, T. (2013) Asas penulisan tesis, penyelidikan \& statistik. Universiti Putra Malaysia Press, Serdang, Selangor.

Pheng, T. L., \& Jaafar, W. (2019). Stigma and Attitudes Toward Seeking Counseling Among Undergraduate Students.

Pedrelli, P., Shapero, B., Archibald, A., \& Dale, C. (2016). Alcohol use and depression during 
adolescence and young adulthood: A summary and interpretation of mixed findings. Curr. Addict. Rep. 3, 91-97. doi: 10.1007/s40429-016-0084-0.

Shah, S. M. A., Mohammad, D., Qureshi, M. F. H., Abbas, M. Z., \& Aleem, S. (2021). Prevalence, Psychological Responses and associated correlates of depression, anxiety and stress in a global population, during the coronavirus disease (COVID-19) pandemic. Community mental health journal, 57(1), 101-110.

Taliaferro, L. A., Rienzo, B. A., Pigg, R. M. Jr, Miller, M. D., \& Dodd, V. J. (2009). Associations between physical activity and reduced rates of hopelessness, depression, and suicidal behavior among college students. Journal of American College Health, 57(4), 427-436.

Tucker, J. R., Hammer, J. H., Vogel, D. L., Bitman, R. L., Wade, N. G., \& Maier, E. J. (2013). Disentangling self-stigma: Are mental illness and help-seeking self-stigmas different? Journal of Counseling Psychology, 60(4), 520. https://doi.org/10.1037/a0033555.

Vazquez, F. L., \& Blanco, V. (2006). Symptoms of depression and related factors among Spanish university students. Psychological reports, 99(2), 583-590.

Vogel, D. L., Wade, N. G., \& Haake, S. (2006). Measuring the self stigma associated with seeking psychological help. Journal of Counseling Psychology, 53(3), 325-337.

Wang, X., Peng, S., Li, H., \& Peng, Y. (2015). How depression stigma affects attitude toward help seeking: the mediating effect of depression somatization. Social Behavior and Personality: an international journal, 43(6), 945-953. 